\title{
MENGUKUR TINGKAT KEPUASAN PELANGGAN TERHADAP PELAYANAN BIRO PERJALANAN TAMARIND WISATA (Performance Importance Method)
}

\author{
Trias Septyoari Putranto; Raden Nana Kusdiana
}

Hotel Management Department, Faculty of Economic and Communication, BINUS University

Jln. K. H. Syahdan No. 9, Palmerah, Jakarta Barat 11480

tputranto@binus.edu; rkusdiana@binus.edu

\begin{abstract}
Research aims to measure the quality of service, and to measure customer satisfaction with the service Travel Bureau (BPW). It can thus be identified variable service according to the needs and expectations of customers as well as the variables that need improvement. Samples taken in this research were customers coming to the BPW office, with a sample size of 110 customers by random sampling of 50 customers. Method of analysis used was Importance-Performance Analysis.
\end{abstract}

Keywords: customer satisfaction, service, travel bureau

\begin{abstract}
ABSTRAK
Penelitian ini bertujuan untuk mengukur kualitas pelayanan dan mengukur kepuasan pelanggan atas pelayanan Biro Perjalanan Wisata (BPW). Dengan demikian, dapat diidentifikasikan variabel pelayanan yang sesuai dengan kebutuhan dan harapan pelanggan serta variabel-variabel yang memerlukan perbaikan. Sampel yang diambil dalam penelitian ini adalah pelanggan yang datang ke kantor BPW, dengan jumlah sampel sebanyak 110 pelanggan dengan random sampling sebanyak 50 pelanggan. Metoda analisis yang digunakan adalah Importance-Performance Analysis.
\end{abstract}

Kata kunci: tingkat kepuasan, pelayanan, biro perjalanan 


\section{PENDAHULUAN}

Industri pariwisata saat ini booming dengan meningkatnya pendapatan masyarakat khususnya dalam negeri, dan bahkan kini Indonesia masuk kelompok penduduk yang berpenghasilan di atas 3.000 dolar. Hal ini membuat permintaan jasa (pariwisata) menjadi banyak diminati. Ini juga berdampak pada banyak bermunculannya usaha kepariwisataan: hotel, restoran, tempat wisata, café, dan biro perjalanan wisata.

Perkembangan dan peningkatan jasa pelayanan pada BPW masih kurang mendapat perhatian. Walaupun demikian, sebenarnya tuntutan untuk peningkatan pelayanan hal ini bisa dilihat dari majunya dan sengitnya persaingan usaha BPW tersebut. Persaingan yang ketat menyebabkan BPW perlu melakukan usaha pelayanan terbaik kepada konsumennya. Hal ini menyebabkan BPW yang ada saling berlomba untuk menyediakan kemudahan dan kelengkapan produk yang sesuai dengan keinginan konsumen agar kepuasan pelanggan tercapai. Strategi instant menjadi salah satu pilihan yang berkembang saat ini. Salah satu di antaranya adalah sistem online reservasi dan delivery service (layanan antar).

Kualitas pelayanan, dalam hal ini pelayanan fasilitas online layanan antar (delivery service) menjadi faktor penting yang berpengaruh dalam penciptaan kepuasan pelanggan. Jika mutu pelayanan yang diterima lebih tinggi dari yang diharapkan, kualitas jasa yang dipersepsikan akan memuaskan. Apabila mutu pelayanan sama dengan yang diharapkan, kualitas dipersepsikan sebagai kualitas yang ideal. Sebaliknya, jika mutu pelayanan yang diterima lebih rendah dari yang diharapkan, kualitas jasa dipersepsikan sebagai kualitas yang buruk dan dapat menjadi masalah bagi perusahaan dalam jangka waktu panjang. Oleh karena itu, baik atau buruknya kualitas jasa tergantung pada kemampuan penyedia jasa dalam memenuhi harapan pelanggannya secara konsisten (Tjiptono, 2000).

Peningkatan kepuasan pelanggan menjadi isu penting karena manfaat yang ditimbulkannya bagi perusahaan. Dalam jangka pendek, kepuasan ditandai dengan terjadinya pembelian ulang (repeat customer). Sedangkan dalam jangka panjang, kepuasan pelanggan menghasilkan loyalitas yang mengarah kepada profitabilitas perusahaan.

Salah satu BPW yang cukup dikenal penulis dan sudah berjalan sejak 10 tahun lalu adalah BPW Tamarind Wisata, dan sampai saat ini masih memiliki pelanggan yang cukup banyak. Oleh karena itu, penulis tertarik untuk melakukan penelitian mengenai "Analisis Kepuasan Pelanggan terhadap Mutu Online dan Layanan Antar (Delivery Service) di BPW Tamarind Wisata.

Penelitian ini bertujuan untuk mengetahui tingkat kepuasan pelanggan terhadap mutu layanan online dan antar (delivery service) di restoran BPW Tamarind Wisata, Semarang (reliability, responsiveness, assurance, emphaty dan tangibles). Sedangkan manfaat dilaksanakannya penelitian ini adalah sebagai bahan rekomendasi bagi perusahaan dalam merumuskan upaya untuk meningkatkan kepuasan konsumen.

\section{Kepuasan Pelanggan}

Gagliano dalam Wiratno (1998) mengatakan bahwa kualitas pelayanan (Service Quality) adalah pandangan konsumen terhadap hasil perbandingan antara ekspektasi konsumen dengan kenyataan yang diperoleh dari pelayanan. Sedangkan kepuasan adalah persepsi pelanggan terhadap satu per satu pengalaman layanan yang diterima (Cronin dan Taylor, 1992). Konsumen akan puas jika pelayanan yang dirasakan sesuai dengan ekspektasinya, sebaliknya konsumen akan kecewa kalau kinerja yang dirasakan di bawah ekspetasinya. Selanjutnya konsumen akan sangat puas kalau kinerja yang didapat melampaui ekspektasinya. Dalam kaitannya dengan hal tersebut, untuk mendapatkan pelanggan yang mempunyai kesetiaan pada suatu perusahaan, maka kepuasan pelanggan menjadi suatu hal yang penting untuk dikelola secara lebih serius. 
Biro Perjalan Wisata (BPW) adalah usaha yang bergerak di bidang jasa pariwisata yang menyediakan segala kebutuhan dalam industri pariwisata (perjalanan). BPW dituntut untuk bisa memberikan pelayanan yang berhubungan dengan perjalanan seperti tiket pesawat, transportasi (darat/laut), hotel, restoran, dll (Harssel, 1997). Sementara itu, Kotler dan Amstrong (1993) menyatakan:

"A Service is any activity or benefit that one party can offer to another that is essentially intangible and does not result in the ownership of anything. Its production may or not be tied to a physical product."

Jasa memiliki 4 karakteristik utama; yaitu (a) intangibility: jasa tidak berwujud, tidak dapat dilihat, diraba, dikecap, didengar atau dicium. Contoh BPW memberikan pelayanan tiket atau hotel voucher. (b) Inseparability: jasa tidak dipisahkan dari sumber pemberi jasa. Contohnya, BPR melakukan transaksi online, telepon, atau datang langsung. (c) Varibility: kualitas jasa beragam bergantung pada penyajian, waktu serta tempat jasa disediakan. Contohnya, BPW memberikan pelayanan berbeda untuk setiap pelanggan. (d) Perishability, jasa tidak dapt disimpan. Contohnya, BPW hanya memberikan pelayanan saat pelanggan melakukan pembayaran. Karena jasa tidak kasat mata serta kualitas jasa tidak dapat dievalusi secara akurat, maka konsumen berusaha menilai kualitas jasa berdasarkan yang dirasakan dengan dibantu atribut-atribut yang mewakili kualitas jasa (Rangkuti, 2002).

\section{Kualitas Jasa}

Salah satu cara agar BPW dapat memberikan pelayan yang terbaik dibandingkan dengan kompetitor, memberikan pelayanan yang berkualitas dan bermutu dapat memenuhi tingkat kepuasan konsumen (Palmer, 1998). Tingkat kepentingan konsumen terhadap jasa yang akan mereka terima dapat dibentuk berdasarkan pengalaman dan saran yang mereka peroleh. Dan setelah menikmati jasa tersebut, mereka cenderung akan membandingkan yang mereka harapkan. Bila jasa yang mereka nikmati ternyata di bawah ekspektasi, pelanggan akan kehilangan minat terhadap BPW tersebut; sebaliknya jika jasa yang mereka nikmati memenuhi atau melebihi tingkat yang diharapkan, mereka akan kembali mengunjungi (pemberi jasa) BPW tersebut.

\section{Dimensi Kualitas Jasa}

Menurut Berry, Parasuraman, dan Zeithaml (1990) kualitas jasa memiliki sepuluh dimensi dasar. Jasa yang diharapkan (expected service) dan jasa yang dirasakan (perceived service) memiliki dimensi yang sama. Dimensi ini dinilai sewaktu pelanggan diminta untuk menyatakan expected dan perceived service yang diterimanya. Tangibles, yaitu bukti fisik dari jasa, baik berupa fasilitas fisik, peralatan yang dipergunakan, representasi fisik dari jasa. Reliability, yaitu mencakup dua hal pokok, konsistensi kerja dan kemampuan untuk dipercaya. Ini berarti perusahaan memberikan jasanya secara tepat sejak pertama. Responsiveness, yaitu kemauan atau kesiapan para karyawan untuk memberikan jasa yang dibutuhkan pelanggan. Competence, artinya setiap orang dalam suatu perusahaan memiliki keterampilan dan pengetahuan yang dibutuhkan agar dapat memberikan jasa tertentu. Courtesy, meliputi sikap sopan santun, respek, perhatian dan keramahan yang dimiliki para contact personnel. Credibility, yaitu sifat jujur dan dapat dipercaya. Security, yaitu aman dari bahaya, risiko atau keragu-raguan. Aspek ini meliputi keamanan secara fisik, keamanan finansial, dan kerahasiaan. Access, meliputi kemudahan untuk dihubungi dan ditemui. Communication, artinya memberikan informasi kepada pelanggan dalam bahasa yang dapat dipahami, serta selalu mendengarkan saran dan keluhan pelanggan. Understanding the customer, yaitu usaha untuk memahami pelanggan. 
Berry et. al. mengkristalkan sepuluh dimensi kualitas jasa tersebut dalam 5 dimensi utama yang kemudian disebutnya dimensi Serqual; atau Analisa Kualitas Layanan yaitu kriteria penilaian atau skala yang terdiri dari ukuran-ukuran mengenai keterandalan dan keefektifan suatu perusahaan untuk dapat mengerti harapan dan persepsi konsumen. Kelima dimensi Serqual itu adalah Tangibles; kualitas pelayanan yang berupa sarana fisik perkantoran, komputerisasi administrasi, ruang tunggu, tempat informasi, dan sebagainya harus dapat diandalkan. Kedua, reliability; kemampuan dan keandalan untuk menyediakan pelayanan yang terpercaya dan akurat. Kinerja harus sesuai dengan harapan pelanggan dan tanpa kesalahan. Ketiga, responsiveness; kesanggupan untuk membantu dan menyediakan pelayanan secara cepat dan tepat, serta tanggap terhadap keinginan konsumen. Keempat, assurance; kamampuan dan keramahan, serta sopan santun pegawai dalam meyakinkan kepercayaan konsumen. Kelima, empathy; sikap tegas tetapi penuh perhatian dari pegawai terhadap konsumen guna memahami keinginan konsumen.

Goetsh dan Davis (1994), yaitu kualitas merupakan suatu kondisi dinamis yang berhubungan dengan produk, jasa, manusia, proses dan lingkungan yang memenuhi atau melebihi harapan. Ada lima perspektif kualitas yang berkembang menurut Tjiptono yang diambil dari Garvim dalam Love Lock, 1994; Ross, 1993, yaitu: transcendental approach; dalam pendekatan ini kualitas dipandang sebagai suatu Innate Excellence, bahwa kualitas dapat dirasakan atau diketahui tetapi sulit didefinisikan dan dioperasionalkan. Product-based Approach; pendekatan ini kualitas dianggap sebagai sesuatu karakteristik atau atribut yang dapat dikuantitatifkan dan dapat diukur. User-based Approach; pendekatan ini didasarkan pada pemikiran bahwa kualitas tergantung pada orang yang memandangnya, sehingga produk yang paling memuaskan preferansi seseorang merupakan produk yang berkualitas tinggi. Manufacturing-based Approach; persepktif ini bersifat supply-based dan terutama memerhatikan praktik-praktik perekayasaan dan pemanufakturan, serta mendefinisikan kualitas sebagai kesesuaian atau sama dengan persyaratan (conformance to requirements). Valuebased Approach; pendekatan ini memandang kualitas dari segi nilai dan harga dengan mempertimbangkan trade of antara kinerja dan harga, kualitas didefinisikan sebagai "Affordable Excellence".

\section{METODE PENELITIAN}

Penelitian dilaksanakan selama satu minggu di BPW tamarind Wisata, Semarang, dengan melakukan interview terhadap konsumen yang datang dan telepon kepada perusahaan. Kualitas pelayanan yang diukur hanya berdasarkan persepsi dari pengguna jasa terhadap pelayanan BPW tersebut. Sampel pelanggan yang diwawancara sebanyak 110 orang. Jumlah tersebut dianggap sudah cukup mewakili. Pemilihan sampel sebanyak 110 didasarkan pada jumlah pengunjung yang datang dan telepon yang masuk selama satu minggu dan sempat di-interview. Pelanggan yang tidak terekam dengan baik dan penentuan besarnya didasarkan pada pendapat bahwa untuk jumlah sampel yang tidak diketahui dengan pasti populasinya, maka 2 sampai 3 kali jumlah variabel dinyatakan mencukupi (Malhotra 1993: 622); dan dengan jumlah variabel sebanyak 17 pertanyaan, maka jumlah sampel yang direncanakan diambil adalah sebanyak 50 sampel. Serta dengan pertimbangan adanya data drop atau hilang, maka ditambahkan 5\% dari total sampel; dan setelah pembulatan maka jumlah yang digunakan adalah sebanyak 110 sampel.

Pengumpulan data dilakukan dengan metode kuesioner atau angket yang pertanyaanpertanyaannya menggambarkan tentang persepsi dan harapan dari pengguna jasa pelayanan BPW Tamarind Wisata di Semarang. Daftar pertanyaan diarahkan untuk mengukur kualitas pelayanan dengan dimensi reliability, responsiveness, assurance, empathy dan tangible. 
Untuk dimensi reliability terdiri dari pertanyaan kemampuan BPW dalam memenuhi layanan yang telah dijanjikan, layanan konsumen yang cepat dan tidak berbelit-belit, layanan pelanggan yang cepat dan tepat serta terjangkau, sikap petugas dalam menghadapi keluhan.

Untuk dimensi responsiveness terdiri dari pertanyaan: kemampuan karyawan untuk cepat tanggap melayani pelanggan, tindakan segera karyawan dalam menyelesaikan masalah, karyawan memberikan informasi yang jelas dan mudah dimengerti, dan pengetahuan dan keterampilan karyawan dalam memberikan layanan. Untuk dimensi assurance terdiri dari pertanyaan karyawan bertindak ramah dan sopan dalam melayani, karyawan memberikan pelayanan secara menyeluruh dan tuntas, dan kemampuan karyawan melakukan komunikasi yang efektif. Untuk dimensi empathy terdiri dari pertanyaan sambutan awak karyawan terhadap konsumen, mendengarkan dengan saksama keluhankeluhan pelanggan, dan waktu operasional. Untuk dimensi tangible terdiri dari pertanyaan kondisi fisik kantor, kebersihan dan kenyamanan ruangan pelayanan, dan perlengkapan untuk memudahkan pelayanan. Metode analisis kondisi layanan BPW terhadap konsumen dengan didukung data dan informasi yang diperoleh, sehingga terlihat secara nyata kondisi pelayanan tersebut, bagaimana kualitas layanan yang diberikan oleh BPW ini. Untuk pengujian reabilitas data ini digunakan rumus keandalan alat ukur berdasarkan metode "Cronbrach" yaitu:

$$
\alpha=\frac{k \cdot r}{1+(k-r) r^{\prime}}
$$

Pengujian keandalan alat ukur ini diperlukan untuk menghitung mean skor kepuasan variabel laten dimensi tangibility, reliability, responsiveness, assurance, dan empathy. Nilai koefisien keandalan alat ukur didefinisikan sebagai seberapa jauh pengukuran bebas dari varian kesalahan acak yang dapat menurunkan tingkat keandalan. Nilai tersebut merupakan konsistensi jawaban responden yang mencerminkan nilai skor sebenarnya. Rentang nilai ini adalah 0 sampai dengan 1 , dengan semakin mendekati angka satu semakin baik alat ukurnya.

\section{Uji Validitas}

Rumus:

$$
\begin{aligned}
& \mathrm{t} \text { hitung }=R_{b t} \times \frac{n-2}{\sqrt{1-R_{b t}^{2}}} \\
& \mathrm{n} \quad=\text { jumlah responden } \\
& \mathrm{Rbt}=\text { Corrected Item Total Correlation } \\
& \mathrm{dk}=\text { Derajat Kebebasan }(\mathrm{dk}=\mathrm{n}-2)
\end{aligned}
$$

Butir pertanyaan dinyatakan valid jika t hitung > t Tabel, maka butir pertanyaan akan dinyatakan valid jika nilai Corrected Item Total Corelation $\mathrm{R}_{\mathrm{b}} \mathrm{t}>\mathrm{t}$ Tabel.

\section{HASIL DAN PEMBAHASAN}

\section{Analisis Deskriptif}

Menurut Arikunto (1993: 353), menganalisis dengan deskriptif adalah memberikan predikat kepada variabel yang diteliti sesuai dengan kondisi yang sebenarnya. Predikat yang diberikan tersebut dalam bentuk sebanding dengan dasar kondisi yang diinginkan. Agar pemberian peringkat dapat tepat, maka sebelum dilakukan pemberian predikat, kondisi tersebut diukur dengan persentase, baru 
kemudian ditransfer ke predikat. Adapun tahapan pengolahan data tersebut terdiri dari: pemeriksaan isian, yaitu isian kuesioner diperiksa kelengkapannya; menganalisis data secara deskriptif dengan cara menghitung rata-rata skor responden untuk tiap butir instrumen; mendeskripsikan secara keseluruhan data dalam bentuk diagramatik.

\section{Analisis Data}

Pertanyaan (kuesioner) ditanyakan (interview) kepada 110 responden. Sebelum mencapai 110 responden telah diuji terlebih dahulu dengan analisis validitas dan reliabilitas pada 25 responden pertama. Validitas dicari dengan membandingkan nilai hitung terhadap nilai $r$ tabel dengan menggunakan tingkat signifikansi 5\%. Pengambilan kesimpulannya jika nilai hitung $>$ dari nilai rtabel maka butir tersebut dinyatakan valid.

Tabel 1 Item-Total Statistics

\begin{tabular}{ccccc}
\hline Variabel & $\begin{array}{c}\text { Scale Mean if } \\
\text { Item Deleted }\end{array}$ & $\begin{array}{c}\text { Scale Variance } \\
\text { if Item Deleted }\end{array}$ & $\begin{array}{c}\text { Corrected Item- } \\
\text { Total Correlation }\end{array}$ & $\begin{array}{c}\text { Alpha if } \\
\text { Item Deleted }\end{array}$ \\
\hline X1.1 & 96.8 & 59.131 & 0.5318 & 0.9347 \\
X1.2 & 96.6333 & 59.6195 & 0.6163 & 0.9335 \\
X1.3 & 96.7667 & 58.8057 & 0.4679 & 0.9364 \\
X1.4 & 96.8333 & 58.1437 & 0.5801 & 0.9341 \\
X2.1 & 96.7 & 59.4586 & 0.5154 & 0.9349 \\
X2.2 & 96.9333 & 58.3402 & 0.6265 & 0.9332 \\
X2.3 & 96.7667 & 59.6333 & 0.5485 & 0.9344 \\
X2.4 & 96.8667 & 58.1885 & 0.6397 & 0.9329 \\
X3.1 & 96.5667 & 59.2195 & 0.6237 & 0.9333 \\
X3.2 & 96.6667 & 58.3678 & 0.7747 & 0.9313 \\
X3.3 & 96.6333 & 58.8609 & 0.7301 & 0.932 \\
X4.1 & 96.9667 & 58.1713 & 0.5321 & 0.9352 \\
X4.2 & 96.6333 & 58.5851 & 0.658 & 0.9327 \\
X4.3 & 96.8 & 58.4414 & 0.6143 & 0.9334 \\
X5.1 & 96.7667 & 58.5299 & 0.6983 & 0.9322 \\
X5.2 & 96.7333 & 59.1678 & 0.6226 & 0.9333 \\
X5.3 & 96.7333 & 58.3402 & 0.6419 & 0.9329 \\
\hline
\end{tabular}

Hasil penghitungan pada tabel 1, dengan nilai Corrected Item Total Correlation berada antara 0,4404 sampai dengan 0,7747. Sedangkan $r$ tabel bernilai 0.3061. Kesimpulannya, nilai hitung lebih besar dari nilai tabel maka butir pertanyaan dinyatakan valid. Untuk menentukan reliabilitas bisa dilihat dari nilai Alpha. Ternyata nilai $r$ hitung lebih besar dari nilai $r$ tabel, bahkan lebih besar 0,60. Dengan demikian, dapat dikatakan reliabel.

\section{Analisis Deskiptif}

BPW Tamarind Wisata di Semarang memiliki 6 unit subkerja/departemen: Dep. Ticketing, Dep. Tour Domestik, Dep. Tour Outbound, Dep. Incentive \& Mice, Dep. Keuangan, Dep. Online, dengan Dep. Usaha tabel 2 dan tabel 3. 
Tabel 2 Tingkat Pendidikan SDM BPW Tamarind Wisata

\begin{tabular}{llcccc}
\hline & & \multicolumn{4}{c}{ Pendidikan Karyawan } \\
\cline { 3 - 6 } No & Departemen & S-2 & S-1 & D-III & $\begin{array}{c}\text { SLTA Atau } \\
\text { Dibawahnya }\end{array}$ \\
\hline 1 & Ticketing & - & 1 & 1 & 4 \\
2 & Tour Domestik & - & 1 & 1 & 3 \\
3 & Tour Outbound & - & 2 & 1 & 2 \\
4 & Inct. \& Mice & - & 2 & 2 & 3 \\
5 & Keuangan & - & 1 & 2 & 2 \\
6 & Online & - & 1 & 3 & 1 \\
\hline & Jumlah & - & $\mathbf{8}$ & $\mathbf{1 0}$ & $\mathbf{1 5}$ \\
\hline
\end{tabular}

Sumber daya manusia BPW Tamarind Wisata di Semarang 25\% berpendidikan S-1, 30\% berpendidikan D-III dan $45 \%$ SLTA.

Tabel 3 memperlihatkan 73,63\% responden perempuan dan 26,36\% responden laki-laki, dengan usia antara 41-60 tahun sebanyak 36,36\%, 21-40 tahun 31,82\%, di atas 60 tahun 20\% dan 1-20 tahun $11,82 \%$.

Tabel 3 Data Responden

\begin{tabular}{lllcccccc}
\hline \multirow{2}{*}{ No } & \multirow{2}{*}{ Departemen } & \multirow{2}{*}{$\mathrm{L}$} & $\mathrm{P}$ & \multicolumn{5}{c}{ Usia (Tahun) } \\
\cline { 5 - 8 } 1 & Ticketing & 6 & 13 & 5 & $17-20$ & $21-40$ & $41-60$ & Diatas 60 \\
2 & Tour Domestik & 7 & 12 & 7 & 7 & 4 & 1 \\
3 & Tour Outbound & 7 & 11 & 0 & 4 & 6 & 8 \\
4 & Inct. \& Mice & 4 & 14 & 0 & 4 & 11 & 3 \\
5 & Keuangan & 2 & 16 & 0 & 8 & 6 & 4 \\
6 & Online & 3 & 15 & 1 & 2 & 10 & 5 \\
Jumlah & & & & & & \\
\end{tabular}

Dari tabel 4 tampak dimensi kualitas pelayanan variabel X1, X2, X3, X4, dan X5 menunjukan kualitas pelayanan BPW Tamarind Wisata sangat baik. Pada skala penilaian 1-5 menunjukan dimensi reliability (keandalan layanan) sebesar 4.32. Dimensi responsiveness (cepat tanggap) dengan nilai 4.3. Dimensi assurance (keramahan) dengan nilai 4.4136. Dimensi empathy (perhatian) dengan nilai 4.2727. Dimensi tangible (sarana fisik) dengan nilai 4.4273, meskipun masih ada salah satu tempat (loket) pendaftaran yang kurang nyaman.

Tabel 4 Descriptive Statistics

\begin{tabular}{lrrcr}
\hline Variabel & N & Minimum & Maximum & Mean \\
\hline X1.1 & 110 & 3 & 5 & 4.4091 \\
X1.2 & 110 & 3 & 5 & 4.3364 \\
X1.3 & 110 & 3 & 5 & 4.2727 \\
X1.4 & 110 & 3 & 5 & 4.2364 \\
X1 & 110 & 3.6 & 5 & 4.32 \\
X2.1 & 110 & 3 & 5 & 4.3545 \\
\hline
\end{tabular}




\begin{tabular}{lrrrr}
\hline X2.2 & 110 & 3 & 5 & 4.2182 \\
X2.3 & 110 & 3 & 5 & 4.3636 \\
X2.4 & 110 & 3 & 5 & 4.2636 \\
X2 & 110 & 3.5 & 5 & 4.3 \\
X3.1 & 110 & 3 & 5 & 4.4727 \\
X3.2 & 110 & 3 & 5 & 4.2455 \\
X3.3 & 110 & 3 & 5 & 4.6182 \\
X3 & 110 & 3.5 & 5 & 4.4136 \\
X4.1 & 110 & 3 & 5 & 4.2727 \\
X4.2 & 110 & 3 & 5 & 4.3455 \\
X4.3 & 110 & 3 & 5 & 4.3273 \\
X4 & 110 & 3.2 & 5 & 4.2727 \\
X5.1 & 110 & 3 & 5 & 4.4364 \\
X5.2 & 110 & 4 & 5 & 4.5182 \\
X5.3 & 110 & 3 & 5 & 4.4636 \\
X5 & 110 & 3.75 & 5 & 4.4273 \\
\hline
\end{tabular}

Nilai tertinggi ada pada variabel X3.3 yaitu 4.6182, artinya bahwa keberadaan BPW Tamarind Wisata sangat disukai pelanggan. Di bawahnya, variabel X5.2 yaitu 4.5182 artinya dari sisi kerapihan dan kebersihan penampilan petugas sangat baik. Demikian juga dengan variabel X3.1 keramahan karyawan dalam melayani pelanggan, sangat baik dan variabel X5.3, kebersihan dan kenyamanan ruang kantor juga sangat baik.

Nilai rata-rata dari semua variabel adalah 4.34. Atau dengan kata lain, kualitas pelayanan BPW Tamarind Wisata, Semarang, sangat baik.

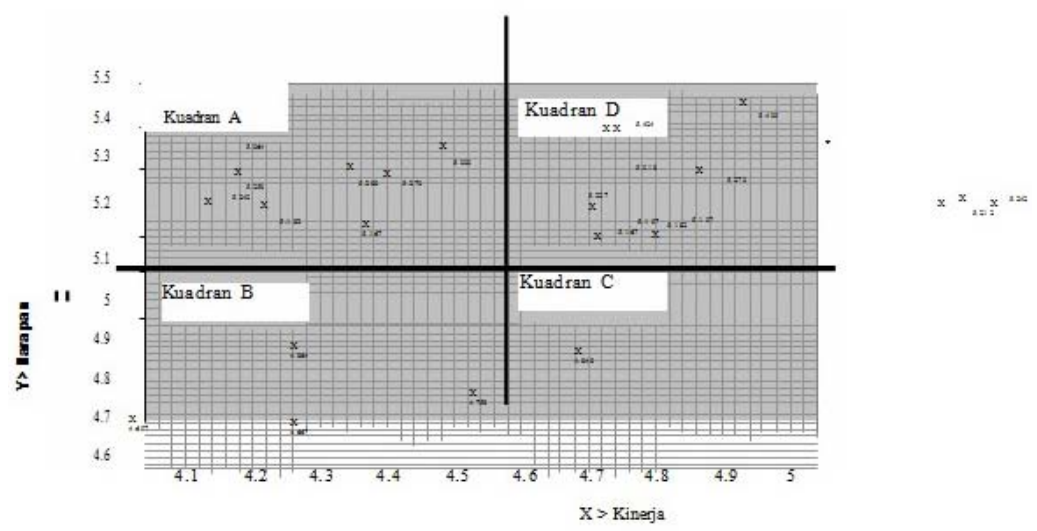

\section{SIMPULAN}

Keberadaan Biro Perjalanan Wisata (BPW) Tamarind Wisata sangat dibutuhkan pelanggan, terutama kaum perempuan dengan usia antara 41-60 dan 21-40 tahun. Kualitas pelayanan BPW ini, mulai dari dimensi reliability (keandalan layanan), responsiveness (cepat tanggap), assurance (keramahan), empathy (perhatian) dan tangible (sarana fisik) adalah sangat baik, terutama keramahan dan kesopanan dalam melayani pelanggan, kerapihan dan kebersihan penampilan petugas serta kebersihan dan kenyamanan ruang kantor untuk pelanggan. Oleh karena kualitas pelayanan sangat 
baik, maka dapat dikatakan bahwa baik secara kualitas maupun kuantitas sumber daya manusia yang ditempatkan di BPW tamarind Wisata, Semarang, benar-benar memadai. Secara fisik bangunan Biro Perjalan Wisata Tamarind Wisata, Semarang, sudah sangat baik. Namun demikian perlu adanya perhatian terkait masih adanya keluhan kekurangnyamanan pada pelayanan online.

\section{DAFTAR PUSTAKA}

Davidow, M. (2000). The bottom line impact of organizational responses to customer complains. Journal of Hospitality \& Tourism Research, Vol. 24 p. 473-490.

Dharmmesta, B., S., dan Handoko, H. (2008). Manajemen Pemasaran, Analisis Perilaku Konsumen. Yogyakarta: BPFE.

Kotler, P. (2000). Manajemen Pemasaran. Jakarta: Prenhallindo.

Kotler, P. (2000). Marketing Management: Analysis, Planning Implementation, and Control. Tenth Edition. Prentice Hall International.

Kotler, P., dan Keller, K., L. (2008). Manajemen Pemasaran. Jakarta: Indeks.

Parasuraman, A., Berry, L. L. (1991). Marketing Service, Competing Through Quality. New York: Free Press, a Division of Mcmillan.

Schiffman, L. G., dan Kanuk, L. L. (2007). Perilaku Konsumen. Jakarta: Indeks.

Setyawan, A. A., \& Susila, I. (2004). Pengaruh servis quality perception terhadap purcase intentions. Usahawan, No. 07, Th. XXXIII, Juli, p. 29-37.

Tjiptono, F. (2004). Pemasaran Jasa. Malang: Bayu Media.

Zeithaml, V. A., Bitner, M. J., dan Gremler, D. D. (2006). Service Marketing: Integrating Customer focus Across the Firm. Fourth Edition. Boston: McGraw-Hill Internasional Edition. 